\title{
Chemistry of ruthenium with some phenolic ligands: synthesis, structure and redox properties
}

\author{
Falguni Basuli ${ }^{a}$, Anjan Kumar Das a , Golam Mostafa ${ }^{\mathrm{b}}$, Shie-Ming Peng ${ }^{\mathrm{c}}$, \\ Samaresh Bhattacharya ${ }^{\mathrm{a}, *}$ \\ ${ }^{a}$ Department of Chemistry, Inorganic Chemistry Section, Jadavpur University, Calcutta 700032, India \\ ${ }^{\mathrm{b}}$ Department of Physics, Krishnath College, Berhampur, West Bengal, India \\ ${ }^{\mathrm{c}}$ Department of Chemistry, National Taiwan University, Taipei, Taiwan, ROC
}

Received 11 January 2000; accepted 11 April 2000

\begin{abstract}
Reaction of three phenolate ligands, viz. salicylaldehyde $\left(\mathrm{HL}^{1}\right)$, 2-hydroxyacetophenone $\left(\mathrm{HL}^{2}\right)$ and 2-hydroxynaphthylaldehyde $\left(\mathrm{HL}^{3}\right)$, (abbreviated in general as $\mathrm{HL}$, where $\mathrm{H}$ stands for the phenolic proton) with $\left[\mathrm{Ru}\left(\mathrm{PPh}_{3}\right)_{3} \mathrm{Cl}_{2}\right]$ in 1:1 mole ratio gives complexes of the type $\left[\mathrm{Ru}\left(\mathrm{PPh}_{3}\right)_{2}(\mathrm{~L}) \mathrm{Cl}_{2}\right]$. The structure of the $\left[\mathrm{Ru}\left(\mathrm{PPh}_{3}\right)_{2}\left(\mathrm{~L}^{2}\right) \mathrm{Cl}_{2}\right]$ complex has been solved by X-ray crystallography. The coordination sphere around ruthenium is $\mathrm{O}_{2} \mathrm{P}_{2} \mathrm{Cl}_{2}$ with a cis-trans-cis geometry, respectively. The $\left[\mathrm{Ru}\left(\mathrm{PPh}_{3}\right)_{2}(\mathrm{~L}) \mathrm{Cl}_{2}\right]$ complexes are one-electron paramagnetic (low-spin $\mathrm{d}^{5}, S=1 / 2$ ) and show rhombic ESR spectra in 1:1 dichloromethane-toluene solution at $77 \mathrm{~K}$. In dichloromethane solution the $\left[\mathrm{Ru}\left(\mathrm{PPh}_{3}\right)_{2}(\mathrm{~L}) \mathrm{Cl}_{2}\right]$ complexes show several intense LMCT transitions in the visible region. Reaction between the phenolic ligands and $\left[\mathrm{Ru}\left(\mathrm{PPh}_{3}\right)_{3} \mathrm{Cl}_{2}\right]$ in 2:1 mole ratio in the presence of a base affords the $\left[\mathrm{Ru}\left(\mathrm{PPh}_{3}\right)_{2}(\mathrm{~L})_{2}\right]$ complexes in two isomeric forms. ${ }^{1} \mathrm{H}$ NMR spectra of one isomer shows that it does not have any $C_{2}$ symmetry and has the cis-cis-cis disposition of the three sets of donor atoms. ${ }^{1} \mathrm{H}$ NMR spectra of the other isomer shows that it has $C_{2}$ symmetry. The structure of the isomer of the $\left[\mathrm{Ru}\left(\mathrm{PPh}_{3}\right)_{2}\left(\mathrm{~L}^{1}\right)_{2}\right]$ complex has been solved by X-ray crystallography. The coordination sphere around ruthenium is $\mathrm{O}_{4} \mathrm{P}_{2}$ with a cis-trans-cis disposition of the carbonylic oxygens, phenolate oxygens and phosphorus atoms, respectively. The $\left[\mathrm{Ru}\left(\mathrm{PPh}_{3}\right)_{2}(\mathrm{~L})_{2}\right]$ complexes are diamagnetic (low-spin $\mathrm{d}^{6}, S=\mathrm{O}$ ) and show intense MLCT transitions in the visible region. Cyclic voltammetry on the $\left[\mathrm{Ru}\left(\mathrm{PPh}_{3}\right)_{2}(\mathrm{~L}) \mathrm{Cl}_{2}\right]$ complexes shows a ruthenium(III)-ruthenium(II) reduction near $-0.3 \mathrm{~V}$ versus SCE and a ruthenium(III)-ruthenium(IV) oxidation in the range 1.08-1.24 V versus SCE. Cyclic voltammetry on both isomers of the $\left[\mathrm{Ru}\left(\mathrm{PPh}_{3}\right)_{2}(\mathrm{~L})_{2}\right]$ complexes shows a ruthenium(II)-ruthenium(III) oxidation within 0.09-0.41 $\mathrm{V}$ versus SCE, followed by a ruthenium(III)-ruthenium(IV) oxidation within 1.31-1.52 V versus SCE. C) 2000 Elsevier Science Ltd. All rights reserved.
\end{abstract}

Keywords: Ruthenium; Phenolic ligands; Synthesis; Structure; Redox properties

\section{Introduction}

The chemistry of ruthenium has currently been receiving a lot of attention [1-10] primarily because of the fascinating electron-transfer and energy-transfer properties displayed by the complexes of this metal. Ruthenium offers a wide range of oxidation states and the reactivities of the ruthenium complexes depend on the stability and interconvertibility of these oxidation

\footnotetext{
* Corresponding author. Fax: +91-33-473-4266.

E-mail address: samaresh_b@hotmail.com (S. Bhattacharya).
}

states, which in turn depend on the nature of ligands bound to the metal. Complexation of ruthenium by ligands of different types has thus been of particular interest. In the present study, which has originated from our interest in the chemistry of ruthenium in different coordination environments [11-18], we have chosen phenolic ligands of type $\mathbf{1}$ as the principal ligand, which are abbreviated in general as HL where $\mathrm{H}$ stands for the dissociable phenolic proton. The deprotonated ligands are known to coordinate metal ions as bidentate $\mathrm{O}, \mathrm{O}$-donor forming six-membered chelate rings (2) $[19,20]$. Three different phenolic ligands have been used in this study, which are shown in $\mathbf{1}$ along with their specific abbreviations. 

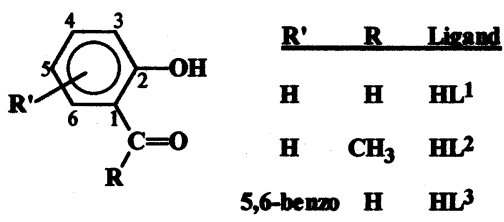

1

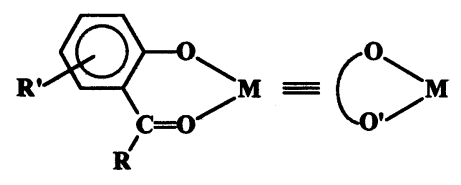

2
While phenolate oxygen is a recognized hard donor, and coordination by it is known to stabilize the higher oxidation states of ruthenium [21-23], coordination of metals by carbonylic oxygen has also recently been of considerable interest in bioinorganic chemistry [24-28]. It may be mentioned here that ruthenium chemistry of these ligands has not been explored much [19]. Stability of different oxidation states of ruthenium is expected to depend on the number of phenolate and carbonylic oxygen in the coordination sphere and in the case of mixed-ligand complexes, on the nature of coligands also. Herein we have restricted our studies to some mono- and bis-phenolate complexes of ruthenium, which have been synthesized by reacting the phenolic ligands with $\left[\mathrm{Ru}\left(\mathrm{PPh}_{3}\right)_{3} \mathrm{Cl}_{2}\right]$ under different experimental conditions. The chemistry of complexes of the type $\left[\mathrm{Ru}\left(\mathrm{PPh}_{3}\right)_{2}(\mathrm{~L}) \mathrm{Cl}_{2}\right]$ and $\left[\mathrm{Ru}\left(\mathrm{PPh}_{3}\right)_{2}(\mathrm{~L})_{2}\right]$ has been described in this paper with special reference to synthesis, stereoisomerism and electron-transfer properties.

\section{Experimental}

\subsection{Materials}

Commercial ruthenium trichloride was purchased from Arora Matthey, Calcutta, India, and was converted into $\mathrm{RuCl}_{3} \cdot 3 \mathrm{H}_{2} \mathrm{O}$ by repeated evaporation with concentrated hydrochloric acid. Triphenylphosphine $\left(\mathrm{PPh}_{3}\right)$, triethylamine $\left(\mathrm{NEt}_{3}\right)$ and salicylaldehyde $\left(\mathrm{HL}^{1}\right)$ were obtained from SD, India. 2-Hydroxyacetophenone $\left(\mathrm{HL}^{2}\right)$ and 2-hydroxynaphthaldehyde $\left(\mathrm{HL}^{3}\right)$ were purchased, respectively, from Spectrochem, India and Aldrich. All other chemicals and solvents were reagent grade commercial materials and were used as received. $\left[\mathrm{Ru}\left(\mathrm{PPh}_{3}\right)_{3} \mathrm{Cl}_{2}\right]$ was prepared following a reported procedure [29]. Purification of acetonitrile and preparation of tetraethylammonium perchlorate (TEAP) for electrochemical work were performed as before [30,31].

\subsection{Preparation of complexes}

\subsection{1. $\left[\mathrm{Ru}\left(\mathrm{PPh}_{3}\right)_{2}\left(\mathrm{~L}^{1}\right) \mathrm{Cl}_{2}\right]$}

$\mathrm{HL}^{1}$ (15 mg, $0.12 \mathrm{mmol}$ ) was added to a suspension of $\left[\mathrm{Ru}\left(\mathrm{PPh}_{3}\right)_{3} \mathrm{Cl}_{2}\right](100 \mathrm{mg}, 0.10 \mathrm{mmol})$ in ethanol (40 $\mathrm{cm}^{3}$ ) and the mixture was stirred for $5 \mathrm{~h}$ to produce a green solution. On partial evaporation of the solvent, $\left[\mathrm{Ru}\left(\mathrm{PPh}_{3}\right)_{2}\left(\mathrm{~L}^{1}\right) \mathrm{Cl}_{2}\right]$ separated out as a green crystalline solid, which was collected by filtration, washed with ethanol and dried in air. The yield was $55 \mathrm{mg}(64 \%)$.

\subsection{2. $\left[\mathrm{Ru}\left(\mathrm{PPh}_{3}\right)_{2}\left(\mathrm{~L}^{2}\right) \mathrm{Cl}_{2}\right]$}

This was synthesized by following the same procedure above using $\mathrm{HL}^{2}$ instead of $\mathrm{HL}^{1}$. The yield was $60 \mathrm{mg}$ $(69 \%)$.

\subsection{3. $\left[\mathrm{Ru}\left(\mathrm{PPh}_{3}\right)_{2}\left(\mathrm{~L}^{3}\right) \mathrm{Cl}_{2}\right]$}

Dichloromethane $\left(40 \mathrm{~cm}^{3}\right)$ was added to a solid mixture of $\left[\mathrm{Ru}\left(\mathrm{PPh}_{3}\right)_{3} \mathrm{Cl}_{2}\right](100 \mathrm{mg}, 0.10 \mathrm{mmol})$ and $\mathrm{HL}^{3}$ (20 mg, $0.12 \mathrm{mmol}$ ) and the solution was stirred for $3 \mathrm{~h}$ to afford a green solution. On evaporation of the solvent, a green solid was obtained, which was washed with ethanol and dried in air. Purification of this product was achieved by chromatography through a silica gel column. Using toluene as the eluent a green band resulted, which was collected. Evaporation of the eluate gave $\left[\mathrm{Ru}\left(\mathrm{PPh}_{3}\right)_{2}\left(\mathrm{~L}^{3}\right) \mathrm{Cl}_{2}\right]$ as a green microcrystalline solid. The yield was $55 \mathrm{mg}(61 \%)$.

\subsection{4. ctc and ccc isomers of $\left[R u\left(P P h_{3}\right)_{2}\left(L^{1}\right)_{2}\right]$}

2.2.4.1. Method $A$. $\left[\mathrm{Ru}\left(\mathrm{PPh}_{3}\right)_{3} \mathrm{Cl}_{2}\right](100 \mathrm{mg}, 0.10 \mathrm{mmol})$ was added to a hot solution of $\mathrm{HL}^{1}(30 \mathrm{mg}, 0.24 \mathrm{mmol})$ in ethanol $\left(40 \mathrm{~cm}^{3}\right)$, followed by $\mathrm{NEt}_{3}(30 \mathrm{mg}, 0.30$ mmol). The mixture was refluxed for $2 \mathrm{~h}$ to produce a red solution. On partial evaporation of solvent, a microcrystalline red solid precipitated, which was collected by filtration, washed thoroughly with water and dried in vacuo over $\mathrm{P}_{4} \mathrm{O}_{10}$. Purification was achieved by chromatography through silica gel column. Using toluene and 1:4 acetonitrile-toluene as the eluents, two different red bands resulted, which were collected separately and evaporation of the eluates, respectively, gave the ctc and ccc isomers of $\left[\mathrm{Ru}\left(\mathrm{PPh}_{3}\right)_{2}\left(\mathrm{~L}^{1}\right)_{2}\right]$. The yield was $30 \mathrm{mg}$ $(33 \%)$ for the ctc isomer and $32 \mathrm{mg}(35 \%)$ for the ccc isomer.

2.2.4.2. Method B. $\left[\mathrm{Ru}\left(\mathrm{PPh}_{3}\right)_{2}\left(\mathrm{~L}^{1}\right) \mathrm{Cl}_{2}\right](50 \mathrm{mg}, 0.06$ $\mathrm{mmol}$ ) was dissolved in a minimum volume of dichloromethane and to it a solution of $\mathrm{HL}^{1}(10 \mathrm{mg}, 0.08 \mathrm{mmol})$ in ethanol $\left(30 \mathrm{~cm}^{3}\right)$ was added, followed by $\mathrm{NEt}_{3}(10$ $\mathrm{mg}, 0.10 \mathrm{mmol})$. The solution was refluxed for $4 \mathrm{~h}$. Upon evaporation of the solution, a red crystalline solid was obtained, which was washed with water and dried in vacuo over $\mathrm{P}_{4} \mathrm{O}_{10}$. The solid was then purified as in Method A. The ctc and ccc isomers of $\left[\mathrm{Ru}\left(\mathrm{PPh}_{3}\right)_{2}\left(\mathrm{~L}^{1}\right)_{2}\right]$ were obtained in 36 and $32 \%$ yields, respectively. 


\subsection{5. ctc and ccc isomers of $\left[\mathrm{Ru}\left(\mathrm{PPh}_{3}\right)_{2}\left(\mathrm{~L}^{2}\right)_{2}\right]$}

These isomers have been prepared by following the above procedures. In method $\mathrm{A}, \mathrm{HL}^{2}$ was used instead of $\mathrm{HL}^{1}$. The ctc and ccc isomers of $\left[\mathrm{Ru}\left(\mathrm{PPh}_{3}\right)_{2}\left(\mathrm{~L}^{2}\right)_{2}\right]$ were obtained in 30 and $34 \%$ yields. In method $\mathrm{B}$ $\left[\mathrm{Ru}\left(\mathrm{PPh}_{3}\right)_{2}\left(\mathrm{~L}^{2}\right) \mathrm{Cl}_{2}\right]$ and $\mathrm{HL}^{2}$ were used instead of $\left[\mathrm{Ru}\left(\mathrm{PPh}_{3}\right)_{2}\left(\mathrm{~L}^{1}\right) \mathrm{Cl}_{2}\right]$ and $\mathrm{HL}^{1}$, respectively. Yields of the ctc and ccc isomers were 35 and $33 \%$, respectively.

\subsection{6. ctc and ccc isomers of $\left[R u\left(P P h_{3}\right)_{2}\left(L^{3}\right)_{2}\right]$}

These isomers have been prepared by following the above procedures (Section 2.2.4). In method $\mathrm{A}, \mathrm{HL}^{3}$ was used instead of $\mathrm{HL}^{1}$. The ctc and ccc isomers of $\left[\mathrm{Ru}\left(\mathrm{PPh}_{3}\right)_{2}\left(\mathrm{~L}^{3}\right)_{2}\right]$ were obtained in 32 and $36 \%$ yields. In method $\mathrm{B},\left[\mathrm{Ru}\left(\mathrm{PPh}_{3}\right)_{2}\left(\mathrm{~L}^{3}\right) \mathrm{Cl}_{2}\right]$ and $\mathrm{HL}^{1}$ were used instead of $\left[\mathrm{Ru}\left(\mathrm{PPh}_{3}\right)_{2}\left(\mathrm{~L}^{1}\right) \mathrm{Cl}_{2}\right]$ and $\mathrm{HL}^{1}$, respectively. Yields of the ctc and ccc isomers were 32 and 34\%, respectively.

\subsection{Physical measurements}

Microanalyses $(\mathrm{C}, \mathrm{H}, \mathrm{N})$ were performed using a Perkin-Elmer 240C elemental analyzer. IR spectra were obtained on a Perkin-Elmer 783 spectrometer with samples prepared as $\mathrm{KBr}$ pellets. Electronic spectra were recorded on Shimadzu UV 240 spectrophotometer. Magnetic susceptibilities were measured using a PAR 155 Vibrating sample magnetometer fitted with a Walker scientific L75FBAL magnet. ${ }^{1} \mathrm{H}$ NMR spectra

Table 1

Crystallographic data

\begin{tabular}{lll}
\hline & {$\left[\mathrm{Ru}\left(\mathrm{PPh}_{3}\right)_{2}\left(\mathrm{~L}^{2}\right) \mathrm{Cl}_{2}\right]$} & ctc-[Ru( $\left.\left(\mathrm{PPh}_{3}\right)_{2}\left(\mathrm{~L}^{1}\right)_{2}\right]$ \\
\hline Formula & $\mathrm{C}_{44} \mathrm{H}_{37} \mathrm{Cl}_{2} \mathrm{O}_{2} \mathrm{P}_{2} \mathrm{Ru}$ & $\mathrm{C}_{50} \mathrm{H}_{40} \mathrm{O}_{4} \mathrm{P}_{2} \mathrm{Ru}$ \\
Formula weight & 831.65 & 867.87 \\
Space group & orthorhombic, Pnma & triclinic, $P \overline{1}$ \\
$a(\AA)$ & $10.5844(10)$ & $10.7368(19)$ \\
$b(\AA)$ & $23.817(2)$ & $11.637(4)$ \\
$c(\AA)$ & $15.407(2)$ & $16.732(7)$ \\
$\alpha\left({ }^{\circ}\right)$ & 90 & $96.18(3)$ \\
$\beta\left({ }^{\circ}\right)$ & 90 & $91.78(3)$ \\
$\gamma\left({ }^{\circ}\right)$ & 90 & $99.44(3)$ \\
$V\left(\AA^{3}\right)$ & $3884.0(8)$ & $2047.7(12)$ \\
$Z$ & 4 & 2 \\
Crystal size $(\mathrm{mm})$ & $0.50 \times 0.30 \times 0.15$ & $0.40 \times 0.30 \times 0.20$ \\
$T(\mathrm{~K})$ & $293(2)$ & 298 \\
$\mu\left(\mathrm{cm}{ }^{-1}\right)$ & 6.60 & 4.951 \\
$R$ & $R_{1}=0.0522^{\mathrm{a}}$ & $R_{\mathrm{f}}=0.046^{\mathrm{d}}$ \\
& $w R_{2}=0.1390^{\mathrm{b}}$ & $R_{\mathrm{w}}=0.047^{\mathrm{c}}$ \\
$\mathrm{GOF}$ & $1.082^{\mathrm{e}}$ & $2.01^{\mathrm{f}}$ \\
\hline
\end{tabular}

\footnotetext{
${ }^{\mathrm{a}} R_{1}=\Sigma\left\|F_{\mathrm{o}}|-| F_{\mathrm{c}}\right\| / \Sigma\left|F_{\mathrm{o}}\right|$.

${ }^{\mathrm{b}}{ }_{\mathrm{w}} R_{2}=\left[\Sigma\left[w\left(F_{\mathrm{o}}^{2}-F_{\mathrm{c}}^{2}\right)^{2}\right] / \Sigma\left[w\left(F_{\mathrm{o}}^{2}\right)^{2}\right]\right]^{1 / 2}$

${ }^{\mathrm{c}} \mathrm{GOF}=\left[\Sigma\left[w\left(F_{\mathrm{o}}^{2}-F_{\mathrm{c}}^{2}\right)^{2}\right] /(M-N)^{1 / 2}\right.$, where $M$ is the number of reflections and $N$ is the number of parameters refined.

${ }^{\mathrm{d}} R_{\mathrm{f}}=\Sigma\left\|F_{\mathrm{o}}|-| F_{\mathrm{c}}\right\| / \Sigma\left|F_{\mathrm{o}}\right|$.

${ }^{\mathrm{e}} R_{w}=\left[\Sigma w\left(\left|F_{\mathrm{o}}\right|-\mid F_{\mathrm{c}}\right)^{2} / \Sigma w\left(F_{\mathrm{o}}\right)^{2}\right]^{1 / 2}$

${ }^{\mathrm{f}} \mathrm{GOF}=\left[\Sigma w\left(\left|F_{\mathrm{o}}\right|-\left|F_{\mathrm{c}}\right|\right)^{2} /(M-N)\right]^{1 / 2}$, where $M$ is the number of reflections and $N$ is the number of parameters refined.
}

were recorded on a Bruker AC-200 spectrometer using TMS as the internal standard. ESR spectra were recorded on a Varian Model 109C E-line X-band spectrometer fitted with a quartz Dewar for measurements at $77 \mathrm{~K}$ (liquid dinitrogen). All spectra were calibrated with the help of DPPH $(g=2.0037)$. Electrochemical measurements were made using a PAR model 273 potentiostat. A platinum disc working electrode, a platinum wire auxiliary electrode and an aqueous saturated calomel reference electrode (SCE) were used in a three electrode configuration. Dinitrogen gas was purified by successively bubbling it through alkaline dithionite and concentrated sulfuric acid. All electrochemical experiments were performed under a dinitrogen atmosphere. All electrochemical data were collected at $298 \mathrm{~K}$ and are uncorrected for junction potentials. An RE 0089 $\mathrm{X}-\mathrm{Y}$ recorder was used to trace the voltammograms.

\subsection{Crystallography}

Single crystals of $\left[\mathrm{Ru}\left(\mathrm{PPh}_{3}\right)_{2}\left(\mathrm{~L}^{2}\right) \mathrm{Cl}_{2}\right]$ were grown by slow diffusion of hexane into a dichloromethane solution of the complex. Selected crystal data and data collection parameters are given in Table 1. Data were collected on a Siemens Smart CCD diffractometer using graphite monochromated Mo $\mathrm{K} \alpha$ radiation $(\lambda=$ $0.71073 \AA$ ) by $\omega$ scans within the angular range $1.57<$ $\theta<25.00^{\circ}$. X-ray data reduction, structure solution and refinement were done using SHELXTL-PLUS package. The structure was solved by direct methods.

Single crystals of ctc- $\left[\mathrm{Ru}\left(\mathrm{PPh}_{3}\right)_{2}\left(\mathrm{~L}^{1}\right)_{2}\right]$ were grown by slow diffusion of benzene into an acetonitrile solution of the complex. Selected crystal data and data collection parameters are given in Table 1 . The unit cell dimensions were determined by a least-squares fit of 25 centered reflections $\left(10.80 \leq \theta \leq 20.94^{\circ}\right)$. Data were collected on an Enraf-Nonius CAD-4 diffractometer using graphite monochromated Mo $\mathrm{K} \alpha$ radiation $(\lambda=0.71073 \AA)$ by $\theta-2 \theta$ scans within the angular range $3.0<2 \theta<45.0^{\circ}$. Three standard reflections, used to check the crystal stability towards X-ray exposure, showed no significant intensity variation over the course of data collection. X-ray data reduction, and structure solution and refinement were carried out using the SHELXS-97 package. The structure was solved by the direct methods.

\section{Results and discussion}

\subsection{Preparation and characterization}

\subsection{1. $\left[\mathrm{Ru}\left(\mathrm{PPh}_{3}\right)_{2}(\mathrm{~L}) \mathrm{Cl}_{2}\right]$ complexes}

Reaction of $\left[\mathrm{Ru}\left(\mathrm{PPh}_{3}\right)_{3} \mathrm{Cl}_{2}\right]$ with an equimolar quantity of each phenolic ligand (HL) proceeds smoothly in dichloromethane solution at ambient temperature to 
Table 2

Microanalytical, electronic spectral and cyclic voltammetric data

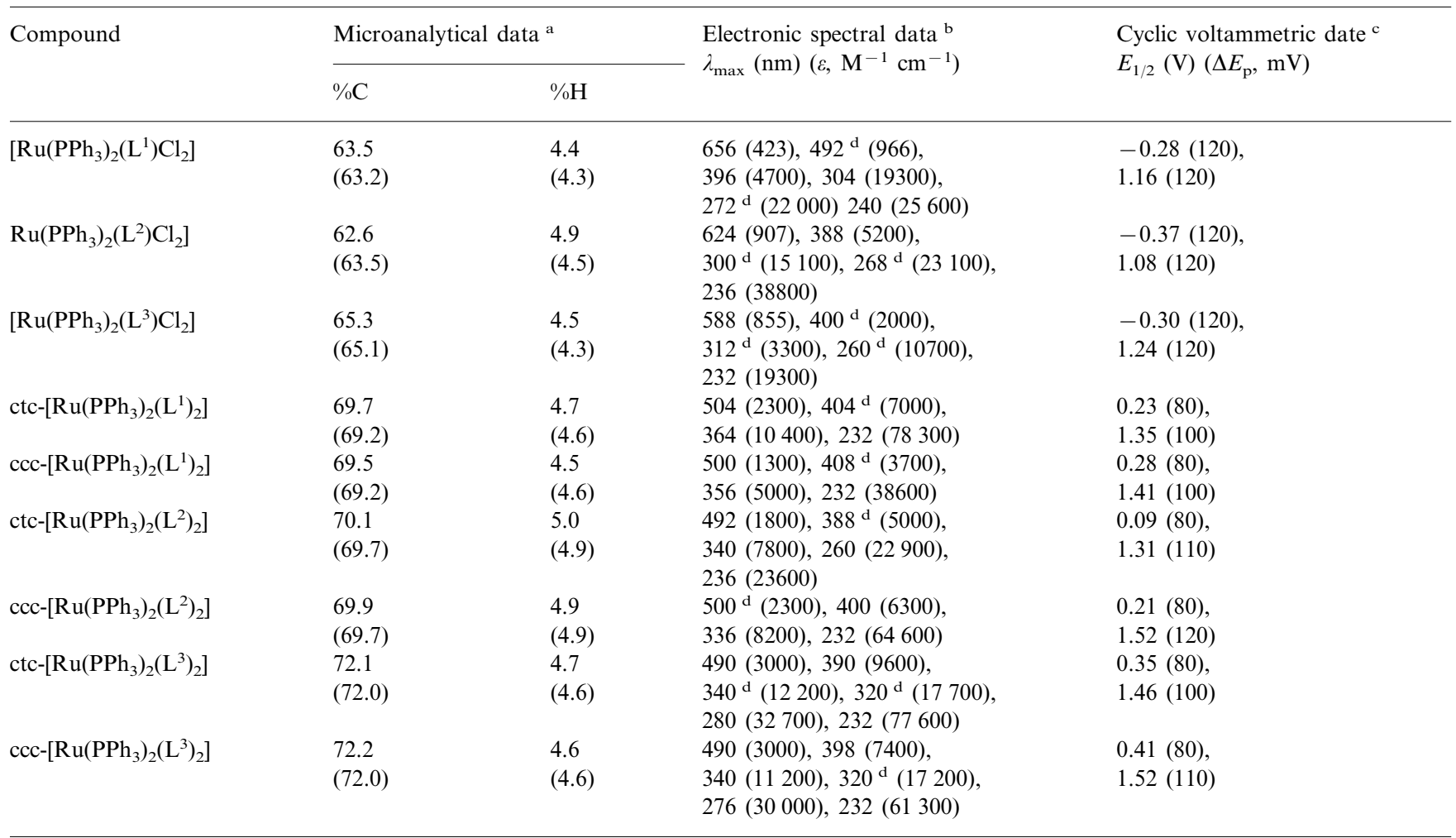

${ }^{\text {a }}$ Calculated values are in parenthesis.

${ }^{\mathrm{b}}$ Dichloromethane solution.

${ }^{\mathrm{c}}$ Solvent, acetonitrile; supporting electrolyte, TEAP; reference electrode, SCE; $E_{1 / 2}=0.5\left(E_{\mathrm{pa}}+E_{\mathrm{pc}}\right)$, where $E_{\mathrm{pa}}$ and $E_{\mathrm{pc}}$ are anodic and cathodic peak potentials, respectively; $\Delta E_{\mathrm{p}}=E_{\mathrm{pa}}-E_{\mathrm{pc}}$; scan rate, $50 \mathrm{mV} \mathrm{s}^{-1}$.

d Shoulder.

afford complexes of the type $\left[\mathrm{Ru}\left(\mathrm{PPh}_{3}\right)_{2}(\mathrm{~L}) \mathrm{Cl}_{2}\right]$. It is interesting to note here that ruthenium has undergone a one-electron oxidation during the course of this synthetic reaction. In view of the ruthenium(III)-rutheniu$\mathrm{m}$ (II) reduction potentials in these complexes (vide infra), oxygen in air appears to have served as the oxidant. Compositions of the complexes have been confirmed by their microanalytical data (Table 2). As all the three phenolate ligands used in the present study are asymmetric bidentate in nature, the $\left[\mathrm{Ru}\left(\mathrm{PPh}_{3}\right)_{2}(\mathrm{~L}) \mathrm{Cl}_{2}\right]$ complexes may exist in three geometric isomeric forms $(\mathbf{3}-\mathbf{5})$.

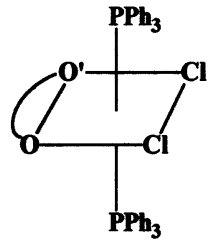

3

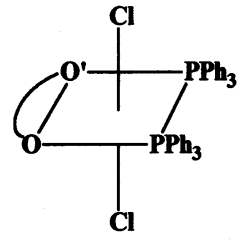

4

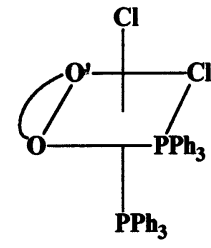

5
To distinguish between the possible three isomers, molecular structure of a representative complex, viz. $\left[\mathrm{Ru}\left(\mathrm{PPh}_{3}\right)_{2}\left(\mathrm{~L}^{2}\right) \mathrm{Cl}_{2}\right]$, has been determined by X-ray crystallography. The structure is shown in Fig. 1 and selected bond distances and angles are presented in Table 3. The $\mathrm{O}_{2} \mathrm{P}_{2} \mathrm{Cl}_{2}$ coordination sphere around ruthenium is distorted octahedral in nature, which is

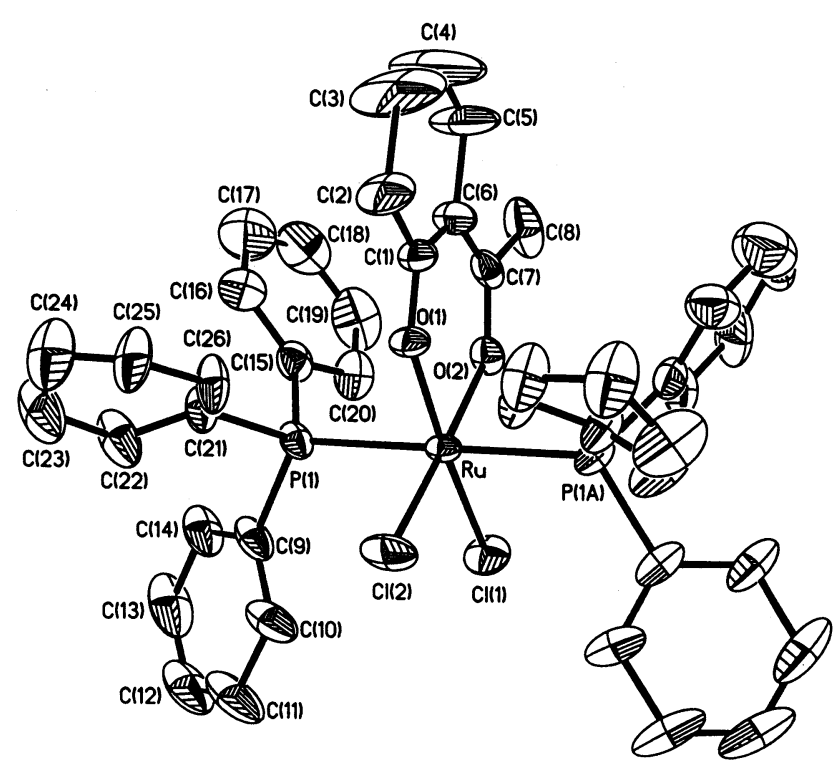

Fig. 1. View of the $\left[\mathrm{Ru}\left(\mathrm{PPh}_{3}\right)_{2}\left(\mathrm{~L}^{2}\right) \mathrm{Cl}_{2}\right]$ molecule. 
Table 3

Selected bond distances $(\AA)$ and bond angles $\left(^{\circ}\right)$ for $\left[\mathrm{Ru}\left(\mathrm{PPh}_{3}\right)_{2}\left(\mathrm{~L}^{2}\right) \mathrm{Cl}_{2}\right]$

\begin{tabular}{llll}
\hline $\mathrm{Ru}-\mathrm{Cl}(1)$ & $2.324(2)$ & $\mathrm{O}(2)-\mathrm{C}(7)$ & $1.298(12)$ \\
$\mathrm{Ru}-\mathrm{Cl}(2)$ & $2.304(2)$ & $\mathrm{O}(1)-\mathrm{C}(1)$ & $1.267(10)$ \\
$\mathrm{Ru}-\mathrm{P}(1)$ & $2.415(2)$ & $\mathrm{C}(1)-\mathrm{C}(2)$ & $1.405(14)$ \\
$\mathrm{Ru}-\mathrm{O}(1)$ & $1.995(5)$ & $\mathrm{C}(2)-\mathrm{C}(3)$ & $1.45(3)$ \\
$\mathrm{Ru}-\mathrm{O}(2)$ & $2.025(6)$ & $\mathrm{C}(3)-\mathrm{C}(4)$ & $1.39(5)$ \\
& & $\mathrm{C}(4)-\mathrm{C}(5)$ & $1.22(4)$ \\
& & $\mathrm{C}(5)-\mathrm{C}(6)$ & $1.44(2)$ \\
& & $\mathrm{C}(6)-\mathrm{C}(7)$ & $1.42(2)$ \\
& & $\mathrm{C}(1)-\mathrm{C}(6)$ & $1.38(2)$ \\
& & $\mathrm{C}(7)-\mathrm{C}(8)$ & $1.494(13)$
\end{tabular}

$\mathrm{O}(2)-\mathrm{Ru}-\mathrm{Cl}(2) \quad 176.9(2)$

$\mathrm{P}(1)-\mathrm{Ru}-\mathrm{P}(1 \mathrm{~A}) \quad 179.41(8)$

$\mathrm{O}(1)-\mathrm{Ru}-\mathrm{Cl}(1) \quad 173.2(2)$

$\mathrm{O}(1)-\mathrm{Ru}-\mathrm{O}(2) \quad 86.4(2)$

$\mathrm{O}(2)-\mathrm{Ru}-\mathrm{Cl}(1) \quad 86.9(2)$

$\mathrm{O}(1)-\mathrm{Ru}-\mathrm{P}(1) \quad 89.73(4)$

$\mathrm{O}(1)-\mathrm{Ru}-\mathrm{Cl}(2)$

$90.5(2)$

$\mathrm{Cl}(2)-\mathrm{Ru}-\mathrm{P}(1)$
$\mathrm{C}(2)-\mathrm{Ru}-\mathrm{Cl}(1)$

$\mathrm{O}(2)-\mathrm{Ru}-\mathrm{P}(1)$

$96.27(11)$

$89.88(5)$
$\mathrm{Cl}(1)-\mathrm{Ru}-\mathrm{P}(1)$
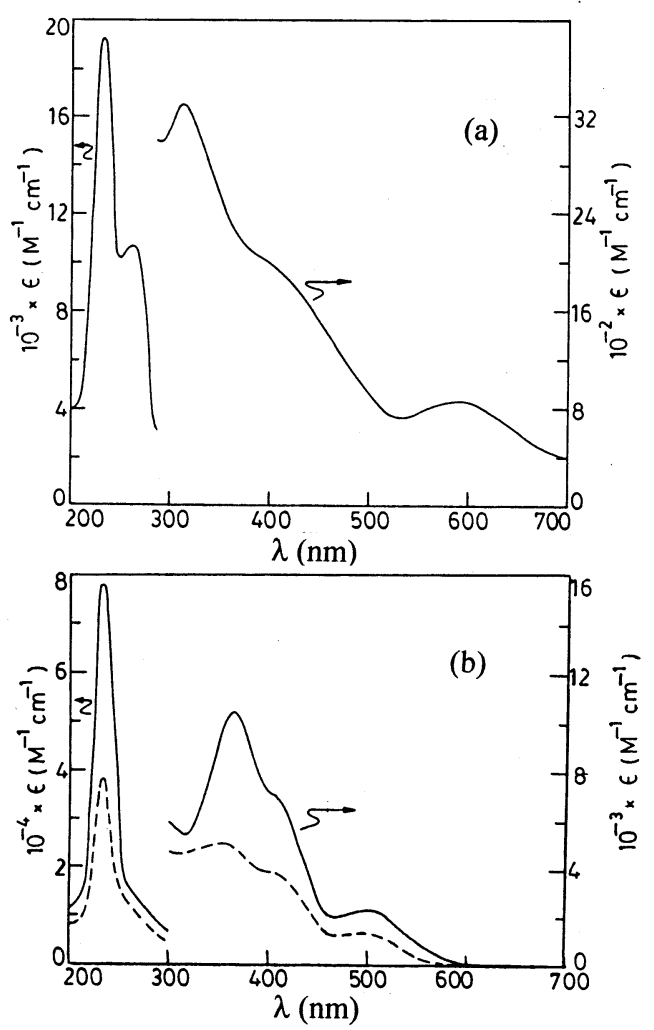

Fig. 2. Electronic spectra of (a) $\left[\mathrm{Ru}\left(\mathrm{PPh}_{3}\right)_{2}\left(\mathrm{~L}^{3}\right) \mathrm{Cl}_{2}\right]$ and (b) ctc$\left[\mathrm{Ru}\left(\mathrm{PPh}_{3}\right)_{2}\left(\mathrm{~L}^{1}\right)_{2}\right] \quad(-)$ and $\quad \mathrm{ccc}-\left[\mathrm{Ru}\left(\mathrm{PPh}_{3}\right)_{2}\left(\mathrm{~L}^{1}\right)_{2}\right] \quad(-----) \quad$ in dichloromethane solution.

reflected in the bond parameters. The two bulky $\mathrm{PPh}_{3}$ ligands are in trans positions, as is usually observed in complexes of ruthenium(III) having the $\mathrm{Ru}\left(\mathrm{PPh}_{3}\right)_{2}$ moiety [32-34], while the two chloride ligands have occupied cis positions. The observed bond distances are all quite normal as observed in structurally characterized complexes of ruthenium containing similar ligands

[19,32-34]. This structure determination thus shows that $\left[\mathrm{Ru}\left(\mathrm{PPh}_{3}\right)_{2}\left(\mathrm{~L}^{2}\right) \mathrm{Cl}_{2}\right]$ has structure 3. As all the three $\left[\mathrm{Ru}\left(\mathrm{PPh}_{3}\right)_{2}(\mathrm{~L}) \mathrm{Cl}_{2}\right]$ complexes display similar properties (vide infra), the other two $\left[\mathrm{Ru}\left(\mathrm{PPh}_{3}\right)_{2}(\mathrm{~L}) \mathrm{Cl}_{2}\right]$ complexes are assumed to have a similar structure as $\left[\mathrm{Ru}\left(\mathrm{PPh}_{3}\right)_{2}\right.$ $\left.\left(\mathrm{L}^{2}\right) \mathrm{Cl}_{2}\right]$.

Infrared spectra of the $\left[\mathrm{Ru}\left(\mathrm{PPh}_{3}\right)_{2}(\mathrm{~L}) \mathrm{Cl}_{2}\right]$ complexes show many sharp and strong vibrations in the 1600-300 $\mathrm{cm}^{-1}$ region, of which the vibrations near 520, 700 and $745 \mathrm{~cm}^{-1}$ are also observed in $\left[\mathrm{Ru}\left(\mathrm{PPh}_{3}\right)_{3} \mathrm{Cl}_{2}\right]$ and hence these are attributable to the $\mathrm{Ru}\left(\mathrm{PPh}_{3}\right)_{2}$ fragment of the $\left[\mathrm{Ru}\left(\mathrm{PPh}_{3}\right)_{2}(\mathrm{~L}) \mathrm{Cl}_{2}\right]$ complexes. One new band, observed near $1580 \mathrm{~cm}^{-1}$ in all these complexes, is assigned to the $v(\mathrm{C}=\mathrm{O})$ vibration of the coordinated phenolate ligand. The $v(\mathrm{Ru}-\mathrm{Cl})$ stretching vibration appears as a strong band in all the complexes near $330 \mathrm{~cm}^{-1}$. The infrared spectral data thus correspond to the composition of the complexes. The $\left[\mathrm{Ru}\left(\mathrm{PPh}_{3}\right)_{2}(\mathrm{~L}) \mathrm{Cl}_{2}\right]$ complexes are soluble in common polar organic solvents, like dichloromethane, chloroform, acetonitrile, etc., producing green solutions. Electronic spectra of these complexes have been recorded in dichloromethane solution. A selected spectrum is shown in Fig. 2 and spectral data are listed in Table 2. Each complex shows few intense absorptions in the visible region together with some very intense absorptions in the ultraviolet region. The absorptions in the ultraviolet region may be assigned to transitions occurring within the ligand orbitals. To have an insight into the nature of transitions appearing in the visible region, qualitative EHMO calculations have been performed $[35,36]$ on a model of the $\left[\mathrm{Ru}\left(\mathrm{PPh}_{3}\right)_{2}(\mathrm{~L}) \mathrm{Cl}_{2}\right]$ complexes, which was computer generated from $\left[\mathrm{Ru}\left(\mathrm{PPh}_{3}\right)_{2}\left(\mathrm{~L}^{1}\right) \mathrm{Cl}_{2}\right]$ by replacing the phenyl groups of the $\mathrm{PPh}_{3}$ ligands with hydrogen. A partial MO diagram is shown in Fig. 3. The highest occupied (singly occupied) molecular orbital (MO-1) and the next two filled orbitals (MO-2 and MO-3) of this model are predominantly $(\geq 80 \%)$ ruthenium $t_{2}$ in character. There are two filled molecular orbitals (MO-4 and MO-5) below these metal $t_{2}$ orbitals, which are localized almost entirely $(\geq 96 \%)$ on the phenolate ligand. The intense absorptions observed in the visible region may therefore be assigned to the allowed ligand-to-metal charge-transfer transitions occurring from the filled orbitals of the phenolate ligand (MO-4 and MO-5) to the half-filled ruthenium $\mathrm{t}_{2}$ orbital (MO-1).

Magnetic susceptibility show that all the three $\left[\mathrm{Ru}\left(\mathrm{PPh}_{3}\right)_{2}(\mathrm{~L}) \mathrm{Cl}_{2}\right]$ complexes are one-electron paramagnetic, which is in accordance with the +3 oxidation state of ruthenium (low-spin $\mathrm{d}^{5}, S=1 / 2$ ) in these complexes. Electron spin resonance spectra of the $\left[\mathrm{Ru}\left(\mathrm{PPh}_{3}\right)_{2}(\mathrm{~L}) \mathrm{Cl}_{2}\right] \quad$ complexes, recorded in 1:1 dichloromethane-toluene solution at $77 \mathrm{~K}$, show rhombic spectra with three distinct signals $\left(g_{1}, g_{2}\right.$ and $g_{3}$ in the order of decreasing magnitude). A representative spectrum is shown in Fig. 4 and the spectral data are 

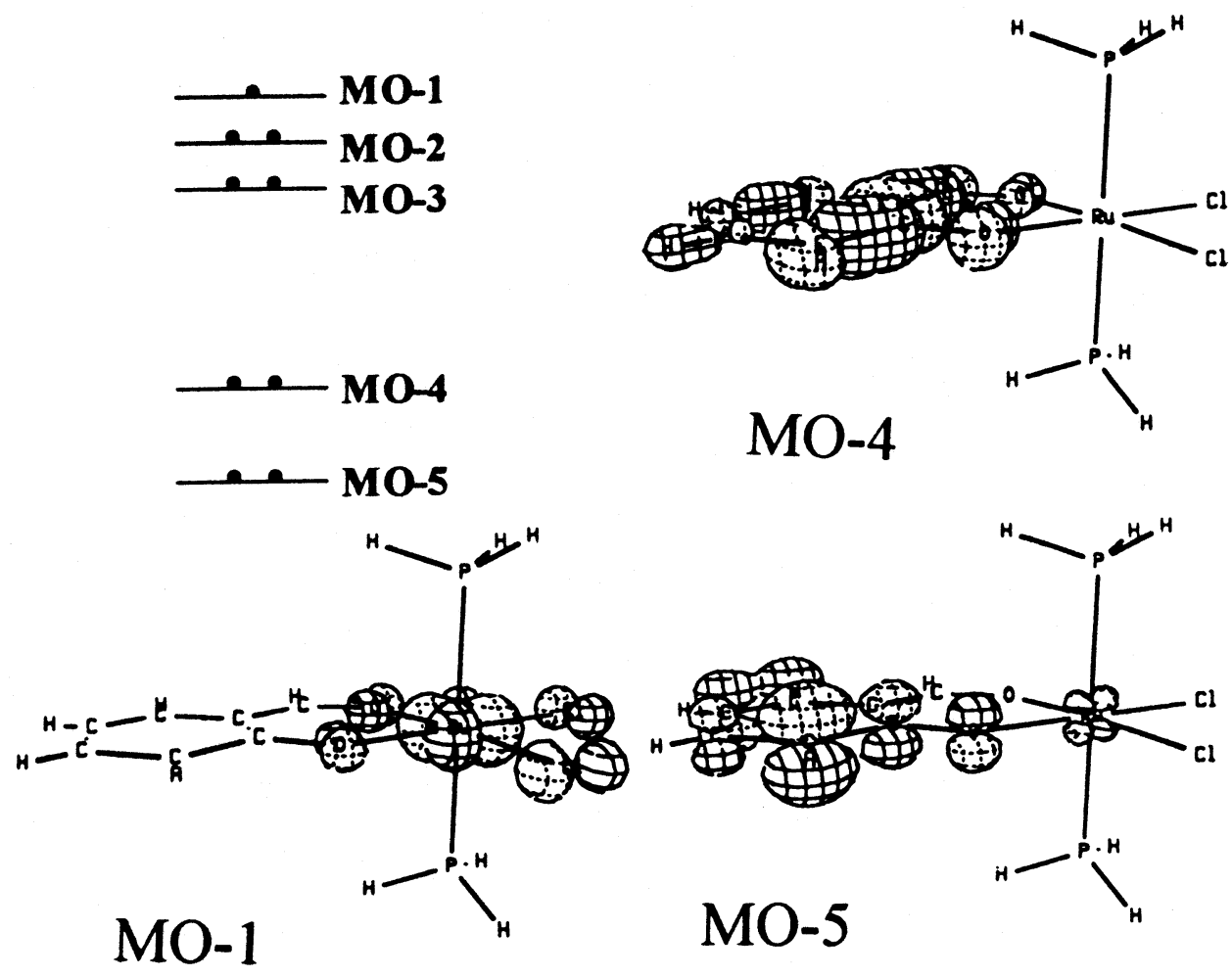

Fig. 3. Qualitative molecular orbital diagram of $\left[\mathrm{Ru}\left(\mathrm{PPh}_{3}\right)_{2}(\mathrm{~L}) \mathrm{Cl}_{2}\right]$.

presented in Table 4. The observed rhombicity of the ESR spectra is understandable in terms of the gross molecular symmetry of these complexes containing the three non-equivalent $\mathrm{P}-\mathrm{Ru}-\mathrm{P}, \mathrm{O}$ (phenolic) $-\mathrm{Ru}-\mathrm{Cl}$ and $\mathrm{O}$ (carbonylic) $-\mathrm{Ru}-\mathrm{Cl}$ axes. The rhombic distortion can be thought of a combination of axial distortion ( $\Delta$, which splits $\mathrm{t}_{2}$ into a and e) and rhombic distortion ( $V$, which splits e). The splitting pattern is illustrated in Fig. 4. Spin-orbit coupling causes further changes in the energy gaps. Thus two electronic transitions (transition energies $\Delta E_{1}$ and $\left.\Delta E_{2} ; \Delta E_{1}<\Delta E_{2}\right)$ are possible within these three levels. All these energy parameters have been computed (Table 4) using the observed $g$ values, the $g$ tensor theory of low-spin $\mathrm{d}^{5}$ complexes and a reported method [37-39]. The axial distortion is observed to be much stronger than the rhombic one. The $\Delta E_{1}$ transition falls in the infrared region $(3200-3700$ $\left.\mathrm{cm}^{-1}\right)$ and could not be detected. The $\Delta E_{2}$ transition, which is expected to occur near $6000 \mathrm{~cm}^{-1}(\sim 1667$ $\mathrm{nm})$, could not be verified either because of the nontransparency of the solvent in this region. However, the ESR data analysis shows that the $\left[\mathrm{Ru}\left(\mathrm{PPh}_{3}\right)_{2}(\mathrm{~L}) \mathrm{Cl}_{2}\right]$ complexes are significantly distorted from ideal octahedral geometry, which was also observed in the structural analysis of $\left[\mathrm{Ru}\left(\mathrm{PPh}_{3}\right)_{2}\left(\mathrm{~L}_{2}\right) \mathrm{Cl}_{2}\right]$.

\subsection{2. $\left[\mathrm{Ru}\left(\mathrm{PPh}_{3}\right)_{2}(\mathrm{~L})_{2}\right]$ complexes}

These complexes have been prepared in two different ways (Scheme 1). Direct reaction of the phenolic lig- ands (HL) with $\left[\mathrm{Ru}\left(\mathrm{PPh}_{3}\right)_{3} \mathrm{Cl}_{2}\right]$ in 2:1 mole ratio proceeds smoothly in refluxing ethanol in the presence of a base to afford the bis complexes of type $\left[\mathrm{Ru}\left(\mathrm{PPh}_{3}\right)_{2}-\right.$ $\left.(\mathrm{L})_{2}\right]$. These complexes can also be prepared from $\left[\mathrm{Ru}\left(\mathrm{PPh}_{3}\right)_{2}(\mathrm{~L}) \mathrm{Cl}_{2}\right]$ by reacting them with one equivalent of the respective phenolic ligand (HL) in the presence of a base. Thin layer chromatographic experiments indicated the presence of two isomers (isomer-I and isomer-II) in all $\left[\mathrm{Ru}\left(\mathrm{PPh}_{3}\right)_{2}(\mathrm{~L})_{2}\right]$ complexes, which have

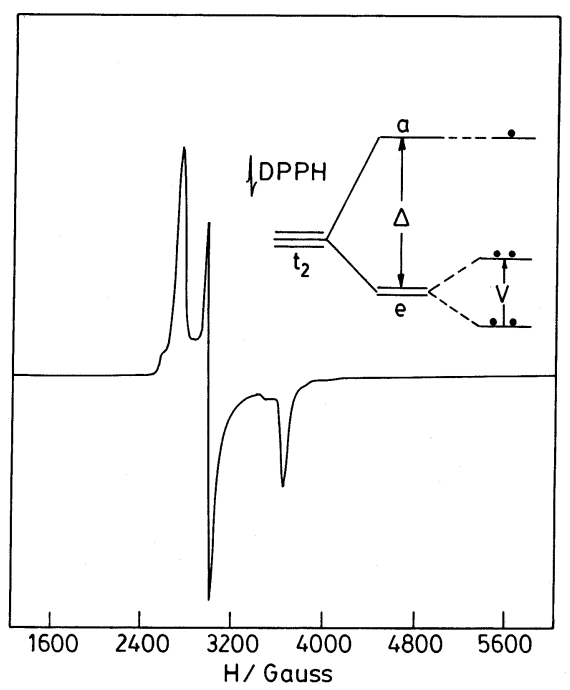

Fig. 4. ESR spectrum of $\left[\mathrm{Ru}\left(\mathrm{PPh}_{3}\right)_{2}\left(\mathrm{~L}^{2}\right) \mathrm{Cl}_{2}\right]$ in $1: 1$ dichloromethanetoluene solution at $77 \mathrm{~K}$. 
Table 4

Magnetic moment and ESR $g$ values a and derived parameters ${ }^{\mathrm{b}}$ of the $\left[\mathrm{Ru}\left(\mathrm{PPh}_{3}\right)_{2}(\mathrm{~L}) \mathrm{Cl}_{2}\right]$ complexes

\begin{tabular}{llllllll}
\hline Compound & $\mu_{\text {eff }}(\mathrm{BM})$ & $g_{1}$ & $g_{2}$ & $g_{3}$ & $\Delta / \lambda$ & $V / \lambda$ & $\Delta E_{1} / \lambda$ \\
\hline$\left[\mathrm{Ru}\left(\mathrm{PPh}_{3}\right)_{2}\left(\mathrm{~L}^{1}\right) \mathrm{Cl}_{2}\right]$ & 1.85 & 2.497 & 2.212 & 1.791 & 4.313 & -2.450 & 3.236 \\
{$\left[\mathrm{Ru}\left(\mathrm{PPh}_{3}\right)_{2}\left(\mathrm{~L}^{2}\right) \mathrm{Cl}_{2}\right]$} & 1.93 & 2.428 & 2.233 & 1.828 & 4.574 & -1.976 & 3.691 \\
{$\left[\mathrm{Ru}\left(\mathrm{PPh}_{3}\right)_{2}\left(\mathrm{~L}^{3}\right) \mathrm{Cl}_{2}\right]$} & 1.97 & 2.407 & 2.258 & 1.795 & 4.065 & -1.264 & 3.515 \\
\hline
\end{tabular}

${ }^{a}$ In 1:1 dichloromethane-toluene solution at $77 \mathrm{~K}$.

${ }^{\mathrm{b}}$ Spin-orbit coupling constant $(\lambda)$ for complexed ruthenium(III) is $\sim 1000 \mathrm{~cm}^{-1}$.

been separated by column chromatography. Microanalytical data of these complexes are in good agreement with their compositions (Table 2). Both isomers of these complexes are diamagnetic, which corresponds to the bivalent state of ruthenium (low-spin $\mathrm{d}^{6}, S=\mathrm{O}$ ) in these complexes.

As all three phenolate ligands used in the present study are asymmetric, the $\left[\mathrm{Ru}\left(\mathrm{PPh}_{3}\right)_{2}(\mathrm{~L})_{2}\right]$ complexes may exist in five geometrical isomeric forms $(\mathbf{6}-\mathbf{1 0})$. Isomers 6-9 have a $C_{2}$ axis, while isomer $\mathbf{1 0}$ does not have any $C_{2}$ symmetry. ${ }^{1} \mathrm{H}$ NMR spectra have been recorded on both isomers of all three $\left[\mathrm{Ru}\left(\mathrm{PPh}_{3}\right)_{2}(\mathrm{~L})_{2}\right]$ complexes in $\mathrm{CDCl}_{3}$ solution. Isomer-I of all three complexes clearly shows the presence of a $C_{2}$ axis, while isomer-II indicates the absence of $C_{2}$ symmetry. For example, isomer-I of $\left[\mathrm{Ru}\left(\mathrm{PPh}_{3}\right)_{2}\left(\mathrm{~L}^{1}\right)_{2}\right]$ shows only one aldehydic proton signal at $8.68 \mathrm{ppm}$, while isomer-II of $\left[\mathrm{Ru}\left(\mathrm{PPh}_{3}\right)_{2}\left(\mathrm{~L}^{1}\right)_{2}\right]$ shows two aldehydic proton signals $(1 \mathrm{H}$ each) at 8.36 and $8.53 \mathrm{ppm}$. This shows that isomer-II has structure 10, where the three sets of donor atoms are in cis positions and henceforth this isomer will be labeled as the cis-cis-cis or ccc isomer.
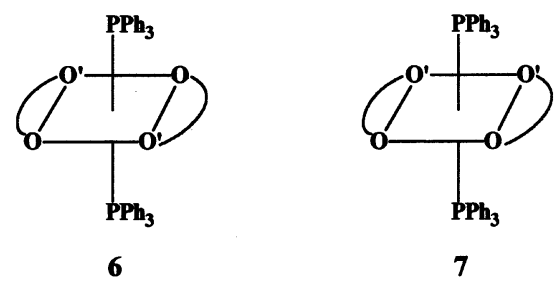

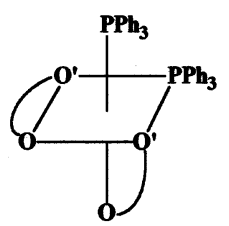

8

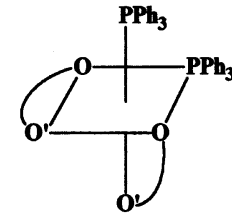

9

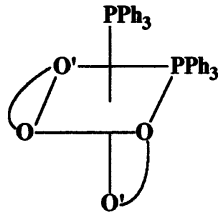

10
It has not been possible to assign specific stereochemistry of isomer-I on the basis of ${ }^{1} \mathrm{H}$ NMR spectral results alone. However, as complexes of ruthenium with the $\mathrm{Ru}\left(\mathrm{PPh}_{3}\right)_{2}$ are known to Prefer cis-disposition of $\mathrm{PPh}_{3}$ ligands $[33,34,40]$, these $\left[\mathrm{Ru}\left(\mathrm{PPh}_{3}\right)_{2}(\mathrm{~L})_{2}\right]$ complexes may be assumed to have either structure 8 or $\mathbf{9}$. To sort out this problem of stereochemistry of isomer-I, the molecular structure of isomer-I of $\left[\mathrm{Ru}\left(\mathrm{PPh}_{3}\right)_{2}\left(\mathrm{~L}^{1}\right)_{2}\right]$ has been determined by X-ray crystallography. The structure is shown in Fig. 5 and selected bond distances and angles are presented in Table 5. Ruthenium has a distorted octahedral $\mathrm{O}_{4} \mathrm{P}_{2}$ coordination sphere with the two $\mathrm{PPh}_{3}$ ligands in cis positions, the two phenolate oxygens in trans positions and the two carbonylic oxygens in cis positions. Therefore isomer-I of $\left[\mathrm{Ru}\left(\mathrm{PPh}_{3}\right)_{2}\left(\mathrm{~L}^{1}\right)_{2}\right]$ has structure 9 (henceforth referred to as the ctc isomer to indicate the cis-trans-cis dispositions of the carbonylic oxygens, phenolate oxygens and phosphines, respectively). The observed bond parameters are all quite normal. In view of the similarity in synthetic procedure and properties, isomer-I of the other two $\left[\mathrm{Ru}\left(\mathrm{PPh}_{3}\right)_{2}(\mathrm{~L})_{2}\right]$ complexes are assumed to have similar ctc structure.

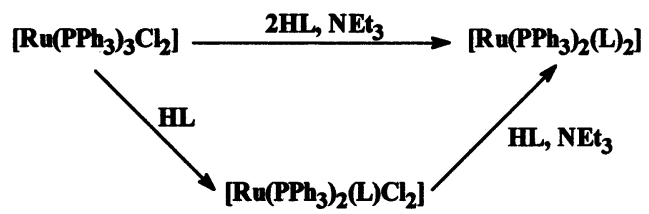

Scheme 1.

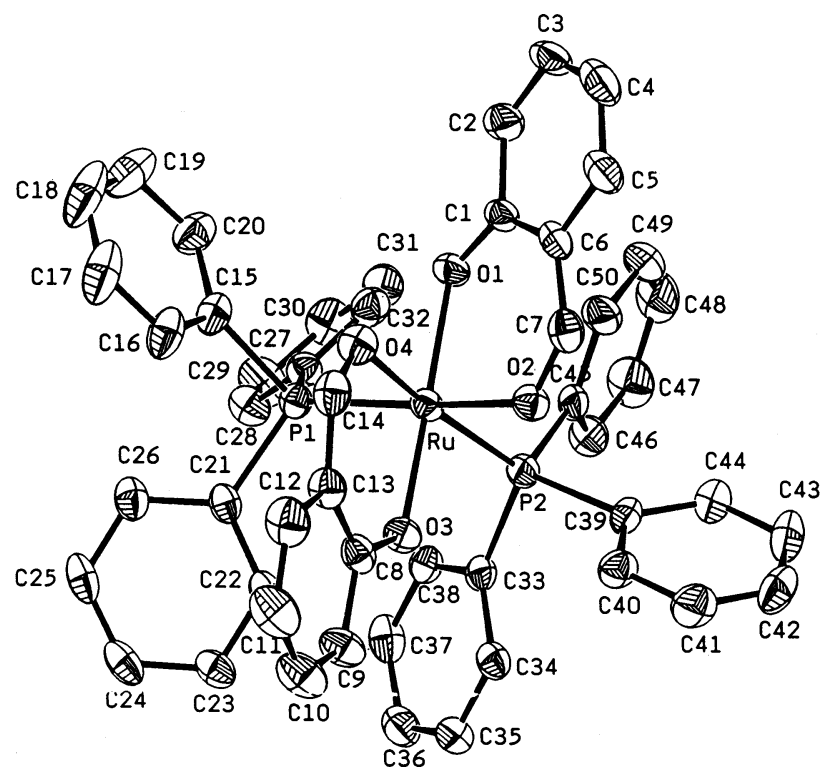

Fig. 5. View of the ctc-[Ru( $\left.\left.\mathrm{PPh}_{3}\right)_{2}\left(\mathrm{~L}^{1}\right)_{2}\right]$ molecule. 
Table 5

Selected bond distances $(\AA)$ and bond angles $\left(^{\circ}\right)$ for $\left[\mathrm{Ru}\left(\mathrm{PPh}_{3}\right)_{2}\left(\mathrm{~L}^{1}\right)_{2}\right]$

\begin{tabular}{llll}
\hline $\mathrm{Ru}-\mathrm{P}(1)$ & $2.2929(18)$ & $\mathrm{O}(1)-\mathrm{C}(1)$ & $1.295(6)$ \\
$\mathrm{Ru}-\mathrm{P}(2)$ & $2.3031(17)$ & $\mathrm{O}(2)-\mathrm{C}(7)$ & $1.239(7)$ \\
$\mathrm{Ru}-\mathrm{O}(1)$ & $2.057(3)$ & $\mathrm{O}(3)-\mathrm{C}(8)$ & $1.313(6)$ \\
$\mathrm{Ru}-\mathrm{O}(2)$ & $2.090(4)$ & $\mathrm{O}(4)-\mathrm{C}(14)$ & $1.262(7)$ \\
$\mathrm{Ru}-\mathrm{O}(3)$ & $2.052(3)$ & & \\
$\mathrm{Ru}-\mathrm{O}(4)$ & $2.128(4)$ & & \\
$\mathrm{P}(1)-\mathrm{Ru}-\mathrm{O}(2)$ & $169.48(11)$ & & \\
$\mathrm{P}(2)-\mathrm{Ru}-\mathrm{O}(4)$ & $169.69(11)$ & & \\
$\mathrm{O}(1)-\mathrm{Ru}-\mathrm{O}(3)$ & $173.61(14)$ & & \\
$\mathrm{P}(1)-\mathrm{Ru}-\mathrm{P}(2)$ & $99.22(6)$ & $\mathrm{P}(2)-\mathrm{Ru}-\mathrm{O}(3)$ & $87.90(11)$ \\
$\mathrm{P}(1)-\mathrm{Ru}-\mathrm{O}(1)$ & $90.17(11)$ & $\mathrm{O}(1)-\mathrm{Ru}-\mathrm{O}(2)$ & $90.75(14)$ \\
$\mathrm{P}(1)-\mathrm{Ru}-\mathrm{O}(3)$ & $93.05(11)$ & $\mathrm{O}(1)-\mathrm{Ru}-\mathrm{O}(4)$ & $83.48(14)$ \\
$\mathrm{P}(1)-\mathrm{Ru}-\mathrm{O}(4)$ & $91.07(11)$ & $\mathrm{O}(2)-\mathrm{Ru}-\mathrm{O}(3)$ & $85.08(14)$ \\
$\mathrm{P}(2)-\mathrm{Ru}-\mathrm{O}(1)$ & $97.04(11)$ & $\mathrm{O}(2)-\mathrm{Ru}-\mathrm{O}(4)$ & $78.62(14)$ \\
$\mathrm{P}(2)-\mathrm{Ru}-\mathrm{O}(2)$ & $91.08(11)$ & $\mathrm{O}(3)-\mathrm{Ru}-\mathrm{O}(4)$ & $90.94(14)$ \\
\hline
\end{tabular}

Infrared spectra of ctc and ccc isomers of the $\left[\mathrm{Ru}\left(\mathrm{PPh}_{3}\right)_{2}(\mathrm{~L})_{2}\right]$ complexes are very similar. Each shows characteristic vibrations near $500,700,750 \mathrm{~cm}^{-1}$, indicating the presence of the $\mathrm{Ru}\left(\mathrm{PPh}_{3}\right)_{2}$ moiety. The $v(\mathrm{C}=\mathrm{O})$ vibration is observed as a strong band near $1580 \mathrm{~cm}^{-1}$ in all these complexes. The $\left[\mathrm{Ru}\left(\mathrm{PPh}_{3}\right)_{2}(\mathrm{~L})_{2}\right]$ complexes are soluble in common organic solvents like dichloromethane, chloroform, acetone, acetonitrile, etc., forming intense red solutions. Electronic spectra of these complexes, recorded in dichloromethane solution, show several intense absorptions in the visible region and few absorptions of very high intensity in the ultraviolet region (Fig. 2, Table 2). The latter absorptions are assigned to transitions within the ligand orbitals. The former absorptions in the visible region are probably due to allowed metal-to-ligand charge-transfer transitions. Multiple charge-transfer transitions are common in such mixed ligand complexes, primarily because of the lower symmetry splitting of the metal orbitals and presence of different accepting orbitals. For proper assignment of the absorptions in the visible region, qualitative EHMO calculations have been performed as before on models of the ctc and ccc isomersa of $\left[\mathrm{Ru}\left(\mathrm{PPh}_{3}\right)_{2}\left(\mathrm{~L}^{1}\right)_{2}\right]$, where phenyl groups of the $\mathrm{PPh}_{3}$ ligands have been replaced by hydrogen. The results of these calculations are qualitatively very similar for both the isomers. A partial MO diagram for one isomer is shown in Fig. 6. The highest occupied molecular orbital (HOMO) and the next two filled orbitals (HOMO-1 and HOMO-2) are basically ( $>75 \%$ ) ruthenium $t_{2}$ orbitals. There are two relatively close vacant molecular orbitals above these filled orbitals, the lowest unoccupied molecular orbital (LUMO) and the next unoccupied orbital (LUMO + 1), which are primarily $(>95 \%)$ $\pi$-orbitals of the phenolate ligands. The intense absorptions observed in the visible region may therefore be assigned to the charge-transfer transitions occurring from the filled ruthenium $t_{2}$ orbitals to the vacant $\pi$-orbitals of the phenolate ligands.

\subsection{Electron-transfer properties}

Electron-transfer properties of the $\left[\mathrm{Ru}\left(\mathrm{PPh}_{3}\right)_{2}(\mathrm{~L}) \mathrm{Cl}_{2}\right]$ and $\left[\mathrm{Ru}\left(\mathrm{PPh}_{3}\right)_{2}(\mathrm{~L})_{2}\right]$ have been studied in acetonitrile solution by cyclic voltammetry. Representative voltammograms are shown in Fig. 7 and voltammetric data are presented in Table 2.

Each $\left[\mathrm{Ru}\left(\mathrm{PPh}_{3}\right)_{2}(\mathrm{~L}) \mathrm{Cl}_{2}\right]$ complex shows a reductive response on the negative side of SCE and an oxidative response on the positive side. Both responses are quasireversible in nature. The reduction, observed near $-0.3 \mathrm{~V}$ (all potentials are referenced to SCE), is tentatively assigned to ruthenium(III)-ruthenium(II) reduction and the oxidation, which occurs within 1.08-
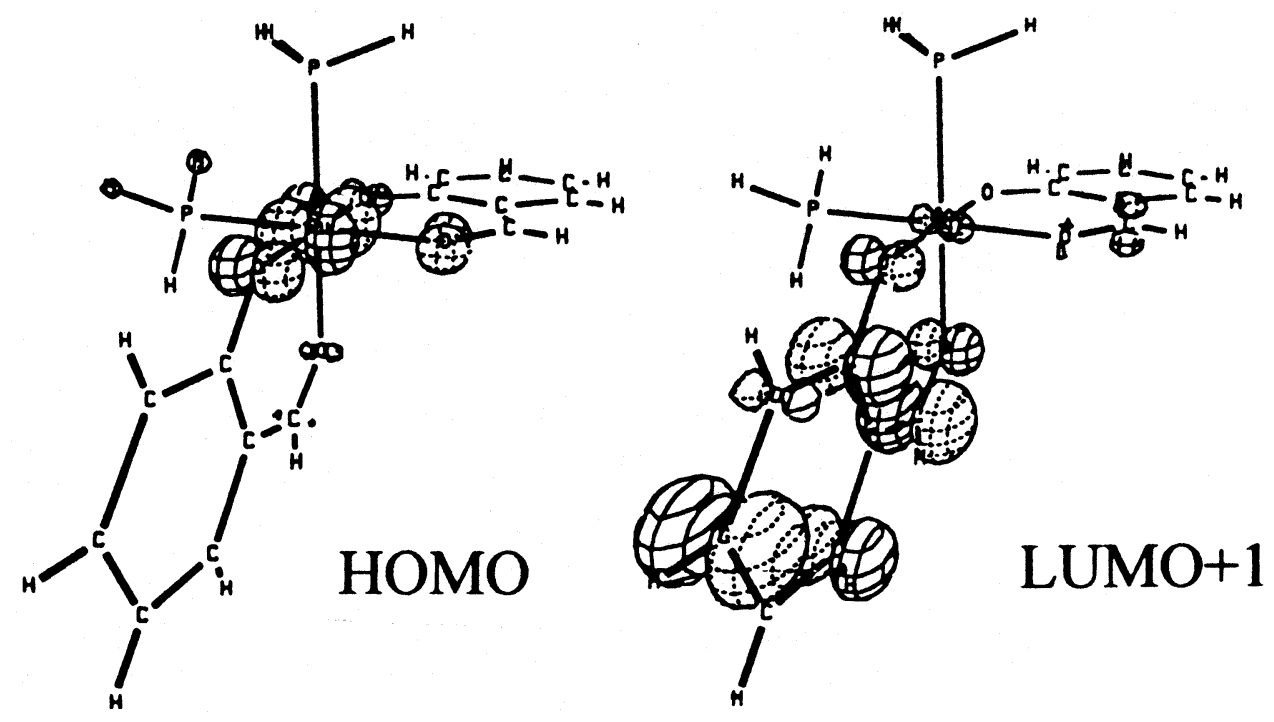

Fig. 6. Qualitative molecular orbital diagram of $\left[\mathrm{Ru}\left(\mathrm{PPh}_{3}\right)_{2}(\mathrm{~L})_{2}\right]$. 


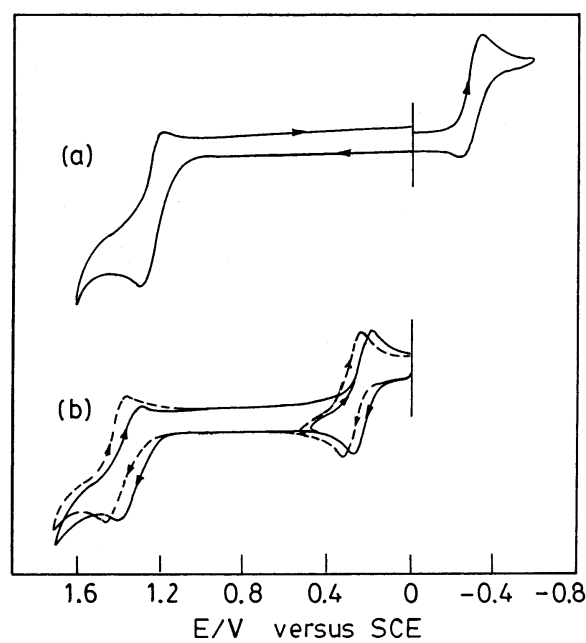

Fig. 7. Cyclic voltammograms of (a) $\left[\mathrm{Ru}\left(\mathrm{PPh}_{3}\right)_{2}\left(\mathrm{~L}^{3}\right) \mathrm{Cl}_{2}\right]$ and (b) ctc- $\left[\mathrm{Ru}\left(\mathrm{PPh}_{3}\right)_{2}\left(\mathrm{~L}^{1}\right)_{2}\right](-)$ and ccc-[Ru( $\left.\left.\left.\mathrm{PPh}_{3}\right)_{2}\left(\mathrm{~L}^{1}\right)_{2}\right](------)\right)$ in acetonitrile solution $\left(0.1 \mathrm{M}\right.$ TEAP) at a scan rate of $50 \mathrm{mV} \mathrm{s}^{-1}$.

$1.24 \mathrm{~V}$, is tentatively assigned to ruthenium(III)-ruthenium(IV) oxidation. Both potentials have shifted to a little more negative values in $\left[\mathrm{Ru}\left(\mathrm{PPh}_{3}\right)_{2}\left(\mathrm{~L}^{2}\right) \mathrm{Cl}_{2}\right]$ relative to $\left[\mathrm{Ru}\left(\mathrm{PPh}_{3}\right)_{2}\left(\mathrm{~L}^{1}\right) \mathrm{Cl}_{2}\right]$, which may be attributed to the electron donating character of the methyl group in $\mathrm{L}^{2}$.

Both isomers of $\left[\mathrm{Ru}\left(\mathrm{PPh}_{3}\right)_{2}(\mathrm{~L})_{2}\right]$ complexes show two oxidative responses on the positive side of SCE. The first oxidation, which is observed within $0.09-0.41 \mathrm{~V}$, is reversible in nature and is assigned to ruthenium(II)ruthenium(III) oxidation. The second quasi-reversible oxidation appears within $1.31-1.52 \mathrm{~V}$ and is tentatively assigned to the ruthenium(III)-ruthenium(IV) oxidation. Potentials of both oxidations have been observed to shift to lower values in the ctc isomer than the ccc isomer, which indicates that the lower oxidation states are more comfortable in the ccc isomer than in the ctc isomer. This is in accordance with the higher probability of $\mathrm{d} \pi-\mathrm{p} \pi$ backbonding in the ccc isomer [41-43]. The oxidation potentials are observed to be a little lower in $\left[\mathrm{Ru}\left(\mathrm{PPh}_{3}\right)_{2}\left(\mathrm{~L}^{2}\right)_{2}\right]$ than in $\left[\mathrm{Ru}\left(\mathrm{PPh}_{3}\right)_{2}\left(\mathrm{~L}^{1}\right)_{2}\right]$, as before. The cyclic voltammetric studies indicate that the +3 state of ruthenium is stable in the $\mathrm{O}_{2} \mathrm{P}_{2} \mathrm{Cl}_{2}$ coordination sphere in the $\left[\mathrm{Ru}\left(\mathrm{PPh}_{3}\right)_{2}(\mathrm{~L}) \mathrm{Cl}_{2}\right]$ complexes and so is the +2 state of ruthenium in the $\mathrm{O}_{4} \mathrm{P}_{2}$ coordination sphere in the $\left[\mathrm{Ru}\left(\mathrm{PPh}_{3}\right)_{2}(\mathrm{~L})_{2}\right]$ complexes.

\section{Supplementary data}

Supplementary data are available from the Cambridge Crystallographic Data Center, 12 Union Road, Cambridge, CB2 1EZ, UK, on request, quoting the deposition numbers CCDC 138541 and 138542.

\section{Acknowledgements}

Financial assistance received from the Council of Scientific and Industrial Research, New Delhi [Grant No. 01(1408)/96/EMR-II] is gratefully acknowledged. Thanks are also due to the Third World Academy of Sciences for financial support for the purchase of an electrochemical cell system. F.B. thanks the University Grants Commission, New Delhi, for her fellowship.

\section{References}

[1] S.-M. Lee, W.-T. Wong, Coord. Chem. Rev. 164 (1997) 415.

[2] I. Ortmanes, C. Moucheron, A.K.-D. Mesmaeker, Coord. Chem. Rev. 168 (1998) 233.

[3] A. Islam, N. Ikeda, K. Nozak, Y. Okamoto, B. Gholamkhass, A Yoshimura, T. Ohno, Coord. Chem. Rev. 171 (1998) 355.

[4] J.W.-S. Hui, Y.-T. Wong, Coord. Chem. Rev. 172 (1998) 389.

[5] P.J. Dyson, B.F.G. Johnson, C.M. Martin, Coord. Chem. Rev. 175 (1998) 59.

[6] D.J. Stufkens, A. Vlcek Jr., Coord. Chem. Rev. 177 (1998) 127.

[7] L.D. Cola, P. Belser, Coord. Chem. Rev. 177 (1998) 301.

[8] S. Sabo-Etienne, B. Chaudret, Coord. Chem. Rev. 178-180 (1998) 381.

[9] D. Touchard, P.H. Dixneuf, Coord. Chem. Rev. 178-180 (1998) 409.

[10] G. Jia, C.-P. Lau, Coord. Chem. Rev. 190-192 (1999) 83.

[11] N.C. Pramanik. S. Bhattacharya, J. Chem. Res. (S) (1997) 98.

[12] F. Basuli, S.M. Peng, S. Bhattacharya, Inorg. Chem. 36 (1997) 5645.

[13] N.C. Pramanik, K. Pramanik, P. Ghosk, S. Bhattacharya, Polyhedron 17 (1998) 1525.

[14] F. Basuli, M. Ruf, C.G. Pierpont, S. Bhattacharya, Inorg. Chem. 37 (1998) 6113.

[15] N.C. Pramanik, S. Bhattacharya, Transition Met. Chem. 24 (1999) 95.

[16] K. Sui, S.M. Peng, S. Bhattacharya, Polyhedron 18 (1999) 631.

[17] A.K. Das, S.M. Peng, S. Bhattacharya, J. Chem. Soc., Dalton Trans. (2000) 181.

[18] F. Basuli, S.M. Peng, S. Bhattacharya, Inorg. Chem. 39 (2000) 1120 .

[19] N. Bag, G.K. Lahiri, S. Bhattacharya, L.R. Falvello, A. Chakravorty, Inorg. Chem. 27 (1988) 4396.

[20] F. Basuli, S.M. Peng, S. Bhattacharya, Polyhedron 17 (1998) 2191.

[21] G.K. Lahiri, S. Bhattachaya, B.K. Ghosh, A. Chakravorty, Inorg. Chem. 26 (1987) 4324.

[22] S. Bhattacharya, S.R. Boone, G.A. Fox, C.G. Pierpont, Inorg. Chem. 29 (1990) 1088.

[23] S. Bhattacharya, Polyhedron 12 (1993) 235.

[24] B. Muller, H. Vahrenkamp, Chem. Eur. J. (1998) 117.

[25] B. Muller, H. Vahrenkamp, Chem. Eur. J. (1998) 129.

[26] B. Muller, H. Vahrenkamp, Chem. Eur. J. (I998) 137.

[27] B. Muller, A. Schneider, M. Tesmer, H. Vahrenkamp, Inorg. Chem. 38 (1999) 1900.

[28] T.R. Ward, A. Lutz, S.P. Parel, J. Ensling, P. Gutlich, P. Buglyo, C. Orvig, Inorg. Chem. 38 (1999) 5007.

[29] T.A. Stephenson, G. Wilkinson, J. Inorg. Nucl. Chem. 28 (1966) 945.

[30] D.T. Sawyer, J.L. Roberts Jr., Experimental Electrochemistry for Chemists, Wiley, New York, 1974, pp. 167-215.

[31] M. Walter, L. Ramaley, Anal. Chem. 45 (1973) 165.

[32] S. Chattopadhyay, N. Bag, G.K. Lahiri, A. Chakravorty, J. Chem. Soc., Dalton Trans. (1990) 3389. 
[33] S. Bhattacharya, C.G. Pierpont, Inorg. Chem. 30 (1991) 1511.

[34] M. Menon, A. Pramanik N. Bag, A. Chakravorty, J. Chem. Soc., Dalton Trans. (1995) 1417.

[35] C. Mealli, D.M. Proserpio, CACAO Version 4.0, Firenze, Italy, July 1994

[36] C. Mealli, D.M. Proserpio, J. Chem. Educ. 67 (1990) 399.

[37] B. Bleany, M.C.M. O'Brien, Proc. Phys. Soc. Lond., Sect B 69 (1956) 1216

[38] J.S. Griffith, The Theory of Transition Metal Ions, Cambridge
University Press, London, 1961, p. 364.

[39] S. Bhattacharya, A. Chakravorty, Proc. Indian Acad. Sci. 95 (1985) 159.

[40] A. Pramanik, N. Bag, G.K. Lahiri, A. Chakravorty, J. Chem. Soc., Dalton Trans. (1990) 3823.

[41] R.A. Krause, K. Krause, Inorg. Chem. 19 (1980) 2600.

[42] S. Goswami, A.R. Chakravarty, A. Chakravorty, Inorg. Chem. 20 (1981) 2246.

[43] R.A. Krause, K. Krause, Inorg. Chem. 21 (1982) 1714. 